\title{
Zero-Energy Cool Chamber in Anthracnose Disease Management of Postharvest Capsicum frutescens
}

\section{Ruang Pendingin Nol Energi untuk Pengelolaan Pascapanen Antraknosa pada Capsicum frutescens}

\author{
Nuzila Fitri Filaila, Suryanti, Ani Widiastuti* \\ Faculty of Agriculture, Universitas Gadjah Mada, Yogyakarta 55281
}

\begin{abstract}
Anthracnose caused by Colletotrichum gloeosporioides is one of important diseases causing postharvest losses on chili. This study aimed to determine the effectiveness of the zero energy cool chamber (ZECC) in reducing the severity of anthracnose in Capsicum frutescens L. and extending the shelf life of chilies. The research was started by designing and building ZECC as a storage area for chilies. Chilies with and without fungal inoculation were stored in ZECC and storage chamber at room temperature. $C$. gloeosporioides experienced a growth inhibition of $40.48 \%$ after being stored in ZECC compared to its growth at room temperature. Storage of chilies in ZECC was able to reduce the severity of anthracnose by $56.2 \%$ on the $15^{\text {th }}$ day, did not affect vitamin C content and total dissolved solids (TSS) and was able to reduce chilies weight loss during storage. Based on the organovisual test using the visual quality rating method and the Hedonic sensory test, consumers prefer chilies stored in the ZECC. The results showed that storage in ZECC could extend the shelf life of chilies. This storage model does not use electricity or is zero energy so it can be used by small scale farmers. This is the first report on the use of ZECC for the management of anthracnose in postharvest chilies in Indonesia.
\end{abstract}

Keywords: Colletotrichum gloeosporioides, postharvest disease, small-scale farmers, storage method

\begin{abstract}
ABSTRAK
Salah satu penyebab kehilangan hasil cabai pascapanen adalah penyakit antraknosa. Penelitian ini bertujuan untuk mengetahui keefektifan ruang pendingin nol energi atau zero energy cool chamber (ZECC) dalam menekan keparahan penyakit antraknosa pada komoditi cabai rawit (Capsicum frustescens) serta memperpanjang daya simpan buah cabai. Penelitian dimulai dengan merancang dan membuat ZECC sebagai tempat penyimpanan cabai. Buah cabai diinokulasi Colletotrichum gloeosporioides dan tanpa inokulasi (kontrol) disimpan pada dua kondisi, yaitu di dalam ZECC dan tempat penyimpanan dengan suhu ruang. Pertumbuhan C. gloeosporioides mengalami penghambatan sebesar $40.48 \%$ setelah disimpan di dalam ZECC dibandingkan dengan pertumbuhannya pada suhu ruang. Penyimpanan cabai rawit di dalam ZECC mampu menekan keparahan penyakit antraknosa sebesar 56.2\% pada hari ke-15, tidak memengaruhi kandungan vitamin $\mathrm{C}$ dan total padatan terlarut (TSS) serta mampu mengurangi susut bobot cabai selama penyimpanan. Berdasarkan uji organovisual dengan metode visual quality rating dan Hedonic sensory test, konsumen lebih menyukai cabai yang disimpan di dalam ZECC. Hasil penelitian menunjukkan bahwa penyimpanan di dalam ZECC dapat memperpanjang umur simpan cabai rawit. Model tempat penyimpanan ini tidak menggunakan listrik atau bersifat zero energy sehingga dapat digunakan oleh petani berskala kecil. Ini adalah laporan pertama penggunaan ZECC untuk pengelolaan penyakit antraknosa pada cabai pascapanen di Indonesia.
\end{abstract}

Kata kunci: Colletotrichum gloeosporioides, metode penyimpanan, penyakit pascapanen, petani berskala kecil

*Alamat penulis korespondensi: Faculty of Agriculture, Universitas Gadjah Mada. Jalan Flora No 1. Bulaksumur-Yogyakarta, 55281.

Telp/Fax: +0274-523926, E-mail: aniwidiastuti@ugm.ac.id 


\section{INTRODUCTION}

Chili is a horticultural commodity which is widely cultivated in Indonesia due to its high economic value. Indonesian people consume chili as fresh, dry, or even processed products in daily life (Taufik 2010). Régo et al. (2011) reported that Capsicum frutescens contains vitamin $\mathrm{C}$ higher than other chili's varieties. In the contrary, vegetables and fruits as perishable products have the highest wastage rate due to improper post-harvest handling which caused significant losses (Kitinoja and Kader 2015). Post-harvest chili contains about $85-95 \%$ of water available which may lead to the metabolic activity including transpiration and respiration after harvest (Rayaguru et. al. 2010). Inappropriate post-harvest storage facilities may effect the vulnerability of chili against pathogens especially Colletotrichum gloeosporiodes, a causal agent of anthracnose disease in chili (Taufik 2011). The pathogen may infect chili from field and continue to develop in storage period.

Post-harvest handling using low temperature is needed to maintain the freshness and quality of chili. The optimum of low temperature depends on the variety and ripening level of chili. Refrigerator usage is the easiest way to provide low temperature condition. However, it will be difficult to be applied by small scale farmers in Indonesia due to the high economic cost (Taufik 2011). Zero-Energy Cool Chamber (ZECC) is an alternative cooling storage with low cost, easy and ecofriendly as the benefits. ZECC can provide lower temperature and higher moisture compared to the surrounding environment without electricity (Islam and Morimoto 2012; Mishra et al. 2020). ZECC applies evaporate cooling system approach with zero energy consumption for its operation (Mishra et al. 2020). This research was conducted to determine the effectiveness of ZECC in post-harvest chili quality and the impact on anthracnose disease development.

\section{MATERIALS AND METHODS}

\section{Construction of ZECC}

This research was conducted at Faculty Agriculture Universitas Gadjah Mada. ZECC construction was built in a flat, clean area and near water sources. The design was created according to Islam and Morimoto (2012) with modification in size (Figure 1). Bottom part of ZECC was layered with a mix of gravel and sand. Then, it was flattened and covered with brick as tray with $75 \mathrm{~cm}(\mathrm{~L})$ and $60 \mathrm{~cm}(\mathrm{~W})$ for size. Wall around ZECC's base was made as a double layer, inner and outer. Dimension of ZECC was as following: the inner layer was $95 \mathrm{~cm}(\mathrm{~L}) \times 75 \mathrm{~cm}(\mathrm{~W}) \times 80 \mathrm{~cm}(\mathrm{H})$; while the outer layer was $120 \mathrm{~cm}(\mathrm{~L}) \times 90 \mathrm{~cm}(\mathrm{~W}) \times$ $80 \mathrm{~cm}(\mathrm{H})$. Space between the outer and inner layers was $7.5 \mathrm{~cm}$ and filled up with material from gravel and sand mixture (3:7). This space must be moistened with water for $15 \mathrm{~L}$ each day. The top surface of ZECC was closed with bamboo straw or coconut's leaves and covered with wet gunny sacks to keep the humidity and temperature inside. Then, shade was made upon the ZECC construction with $4 \mathrm{~m}$ height.

\section{Effect of Storage Conditions on Mycelial Growth of $\boldsymbol{C}$. gloeosporioides Isolate}

C. gloeosporioides isolate CBIL-1 (collection of Laboratory of Plant Disease, Dept. of Plant Protection, Fac. of Agriculture, UGM) was cultured on PDA medium and incubated in different condition, i.e. in ZECC and in laboratory. Mycelial growth of the fungus was measured every 2 days during 17 days' observation. Three replications were prepared for this observation. Temperature $\left({ }^{\circ} \mathrm{C}\right)$ and relative humidity $(\%)$ inside and outside ZEEC, and in laboratory (room temperature) were measured using a thermohygrometer every 2 days during.

\section{Experimental Design}

The experiment was conducted in a completely randomized design with 4 treatments and 4 replications. Fresh healthy chili fruits (C. frustecens var. Rajo) harvested at the same time were first disinfected by wiping using $\mathrm{EtOH} 70 \%$, then subjected for treatment as follow:

ZECC.n : Chili was stored in ZECC room without fungal inoculation

ZECC.in : Chili was stored in ZECC room with fungal inoculation

Room.n :Chiliwas stored in room temperature $\left(24-26^{\circ} \mathrm{C}\right)$ without fungal inoculation 
Room.in : Chili was stored in room temperature $\left(24-26^{\circ} \mathrm{C}\right)$ with fungal inoculation

Chili fruits were placed in a tray for each treatment, consisted of 4 fruits as replication for each treatment and sampling's day. Fungal inoculation was conducted by spraying spore suspension until run off. Destructive samplings were conducted every 2 days until 12 days' observation plus day $15^{\text {th }}$ for disease incidence and disease severity and every 3 days for organovisual test. As destructive samples were applied, fruits after observation were discarded. There were 128 chili fruits prepared for disease incidence and severity ( 4 treatments $\times 8$ observations $\times 4$ sample replications), 64 fruits for organovisual test (4 treatments $\times$ 4 observations $\times 4$ sample replications) and 48 fruits for vitamin $\mathrm{C}$ content, total soluble solid (TSS), weight loss measurement
(4 treatments $\times 3$ parameters $\times 4$ replication. Therefore, totally 240 fruits were applied in this experiment.

\section{Assessment of Disease Incidence and Severity}

Disease incidence was calculated as amount of infected chili sample in total of chili observed in each treatment, whereas disease severity was calculated following the formula below:

$$
\mathrm{DS}=\frac{\sum(\mathrm{n} \times \mathrm{v})}{\mathrm{N} \times \mathrm{Z}} \times 100 \% \text {, with }
$$

$n$, number of infected chili in the certain $v$ score; $\mathrm{v}$, rating score; $\mathrm{N}$, total number of observed chili; $Z$, maximum rating score

Scoring for anthracnose disease severity followed Montri et al. (2009) with modification by adding figure (Table 1 ).

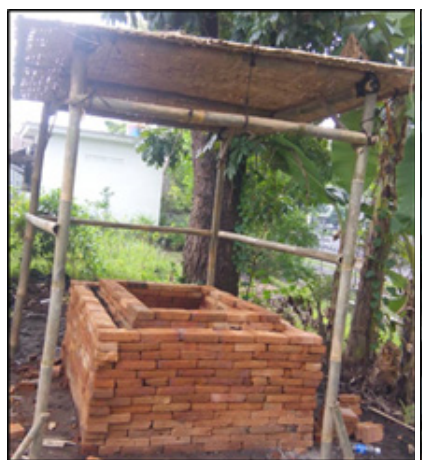

$\mathrm{a}$

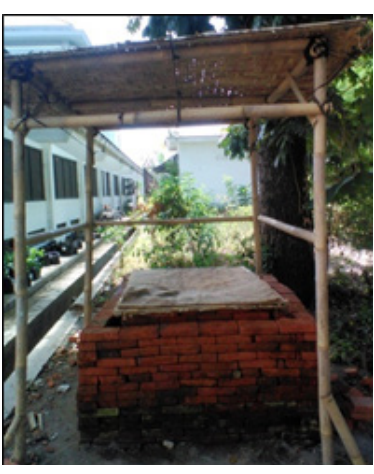

b

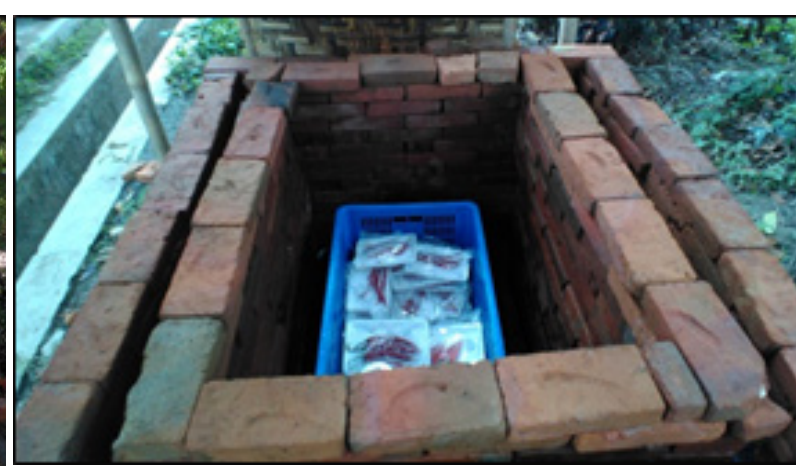

c

Figure 1 ZECC construction. a and b, Front side; c, Postharvest chili stored inside ZECC.

Table 1 Score for disease severity of anthracnose in chili based on symptom

\begin{tabular}{c} 
Score \\
\hline
\end{tabular}


Effect of Storage Condition on Postharvest Chili Quality

Parameters for this experiment consisted of vitamin C content, total soluble solid (TSS), weight loss and organovisual test.

Vitamin $\mathbf{C}$ content. Vitamin $\mathrm{C}$ content was determined based on ascorbic acid content at 15 days after storage (Régo et al. 2011). As many as $10 \mathrm{~g}$ of chili fruit from each treatment was extracted using mortar or electrical mixer. The extract was added with $100 \mathrm{~mL}$ aquadest, stirred and filtered using filter paper. Then, $1 \mathrm{~mL}$ of amylum $1 \%$ were mixed with $25 \mathrm{~mL}$ of chili's extract and titrated with $0.01 \mathrm{~N}$ of Potassium Iodide $(0.01 \mathrm{~N}=$ $0.8806 \mathrm{mg}$ of ascorbate acid/ vitamin C) until the color changed. The ascorbic acid content was calculated using formula described in Régo et al. (2011) as below:

Vitamin $\mathrm{C}$ content $=\frac{\mathrm{mL} 0.001 \mathrm{~N} \text { titrated } \times 0.8806 \times 100}{\text { sample weight }}$

Total Soluble Solid (TSS). Measurement of TSS was carried out using a refractometer as described by Tsegay et al. (2013). Test was done by first extracting chili using mortar; then the extract was titrated into refractometer until the notation on that machine were appeared and showed the TSS score. TSS score was measured at 15 days after storage.

Weight loss. Weight loss during storage were measured using electric balance by the formula:

$$
\text { Weight loss }=\frac{X 1-X}{X} \times 100 \% \text {, with }
$$

$\mathrm{X} 1$, initial weight $(\mathrm{g})$ and $\mathrm{X}$, weight $(\mathrm{g})$ at the end of storage time (15 days).

Organovisual test. Organovisual test was used to assess the fruit performance based on their shape and visual performance such as fruit decay. Organovisual assessment was measured based on Visual Quality Rating (VQR) and Hedonic sensory test which were conducted independently by 7 volunteers in every observation's day. VQR aimed to determine the quality of chili based on visual performance and Hedonic sensory test was conducted to collect the consumers preference toward fruits samples. Each volunteer chose the criteria of assessment which were presented in scoring table for VQR (Table 2) and Hedonic sensory test (Table 3). Hedonic sensory test is examined for understanding the consumers' preference on the fruit during storage period. The assessment was conducted using questionnaire and score according to the shape and color of chili fruit. Both evaluations were conducted every 3 days during 9 days period. Three chili fruits were used as replication.

\section{Data analysis}

Data of mycelial growth was analyzed by t test, while vitamin C content, TSS, weight loss, and organovisual test were analyzed using anova in completely random design. LSD test with level of confident as much as $95 \%$ was used for further significant different result.

\section{RESULT}

\section{Mycelial Diameter of C. gloeosporioides Isolate}

The minimum and maximum temperature inside the ZECC, outside ZECC (environment) and in laboratory (room temperature) were $21{ }^{\circ} \mathrm{C}$ and $23{ }^{\circ} \mathrm{C} ; 26{ }^{\circ} \mathrm{C}$ and $29.5^{\circ} \mathrm{C} ; 24.5^{\circ} \mathrm{C}$ and $26{ }^{\circ} \mathrm{C}$, respectively (Figure 2). Relative humidity during 17 days observation was stable in ZECC while it varied in other

Table 2 Visual Quality Rating (VQR) score

\begin{tabular}{ll}
\hline Score & Description \\
\hline 6 & Perfect/ very good, fresh \\
5 & Good, small damage \\
4 & Average, medium damage \\
3 & Bad, not for sale cause of serious \\
2 & damage \\
1 & Limited part of fruit to eat \\
\hline
\end{tabular}

Table 3 Hedonic sensory test score

\begin{tabular}{ll}
\hline Score & Description \\
\hline 5 & Very like \\
4 & Like \\
3 & Neutral (neither like or dislike) \\
2 & Dislike \\
1 & Very dislike \\
\hline
\end{tabular}


conditions especially outside ZECC. Relative humidity inside ZECC ranges from $85 \%$ to 99\%, while outside ZECC ranges from $46 \%$ to $85 \%$ and in room temperature ranges from $50 \%$ to $66 \%$.

Mycelial diameter of C. gloeosporiodes inside ZECC was significantly reduced compared to those incubated in room temperature during 17 days' observation. In the day $17^{\text {th }}$, the average of mycelial diameter of C. gloeosporiodes incubated in ZECC was $4.19 \mathrm{~cm}$, while it was $7.04 \mathrm{~cm}$ in the laboratory room. It showed that the mycelial diameter was reduced up to $40.48 \%$ (Figure 3 ).

\section{Disease Incidence and Severity}

Natural infection of $C$. gloeosporioides was shown in uninoculated chili after 10 days in ZECC and 12 days in room temperature with disease incidence as low as $12.5 \%$ in 15 days' storage. In contrast, disease incidence of inoculated chili reached $75 \%$ and $100 \%$ when it stored in ZECC and in room temperature, respectively (Figure 4).

Similarly, disease severity for inoculated chili stored in ZECC was lower (43.8\%) compared to those stored in room temperature $(100 \%)$, while disease severity for uninoculated chili stored in ZECC and room temperature each reached $12.5 \%$ (Figure 5). These data showed that disease severity of anthracnose was suppressed up to $56.2 \%$ when the chili fruits were kept in ZECC. Anthracnose symptom appeared on 6 days for chili stored in room temperature, while it was 10 days for chili stored in ZECC (Figure 4 and 5).

\section{Postharvest Chili Quality After Storage Period}

Vitamin C content and TSS of postharvest chili stored at ZECC and room temperature condition were not significantly different (Table 4). Weight loss reached the highest on inoculated chili stored at room temperature $(14.89 \%)$ which was significantly different from other treatments; while the lowest was obtained by uninoculated chili stored in ZECC (5.53\%). Most chilies stored at ZECC condition showed better appearance compared to those stored at room temperature. Figure 6 showed the morphology of chili fruits after 9 days storage in the different room treatment.

The effect of storage conditions was obvious according to VQR and hedonic sensory test (Figure 7). Based on VQR analysis, non-inoculated chili stored in ZECC had the highest score for good appearance (score 5). Both inoculated and non-inoculated chili fruits stored in ZECC showed no significance appearance, while chili fruits stored at room temperature showed lower score of VQR. According to the result of hedonic sensory test, postharvest chili stored in ZECC was more preferable by customers than chili stored in room storage both inoculated and noninoculated treatment. Moreover, score of those
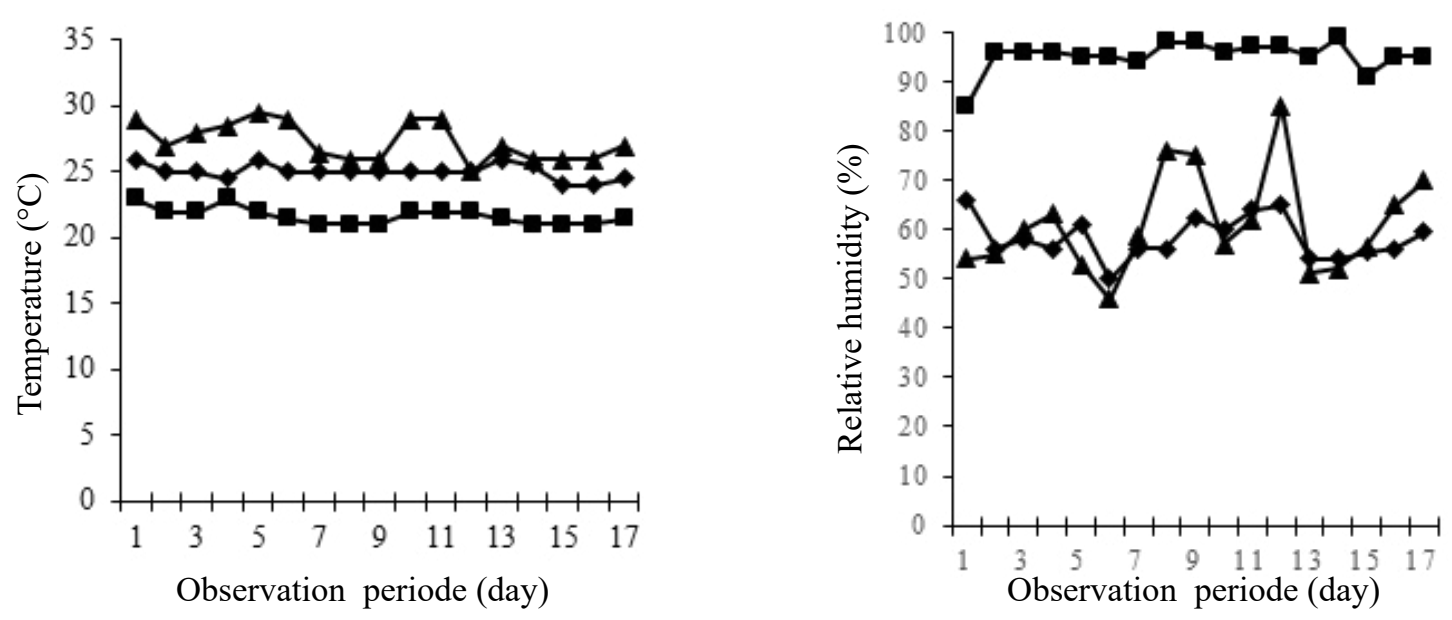

Figure 2 Daily temperature $\left({ }^{\circ} \mathrm{C}\right)$ and relative humidity $(\%)$ in laboratory room $(\leadsto)$, ZECC ( $\neg$ ), and outside ZECC ( $\leftarrow$ ). 


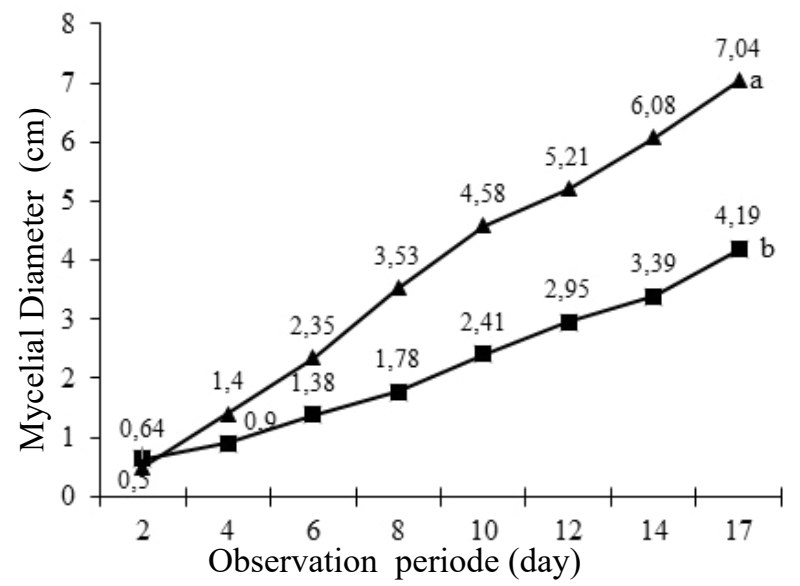

Figure 3 Mycelial diameter growth of $C$. gloeosporiodes stored in ZECC ( $\rightarrow$ )and laboratory room ( $\leftarrow$ ) storage. Analysis data was done by $\mathrm{t}$ test followed by LSD with $\mathrm{p}=0.05$. Different alphabet showed significant difference between those treatments. uninoculated chili stored in ZECC at 9 days was not significantly different from data on previous observation (day $6^{\text {th }}$ ).

\section{DISCUSSION}

Low temperature and high relative humidity attained in ZECC storage during this experiment showed that they played important role for inhibiting the $C$. gloeosporioides mycelial growth, keeping the chili freshness and reducing development of anthracnose disease. Inhibition of fungal growth was shown as early as 2 days after chili fruits was put into ZECC storage and it increased with storage time. Inhibition of fungal growth consequently resulted on lower disease severity. Disease

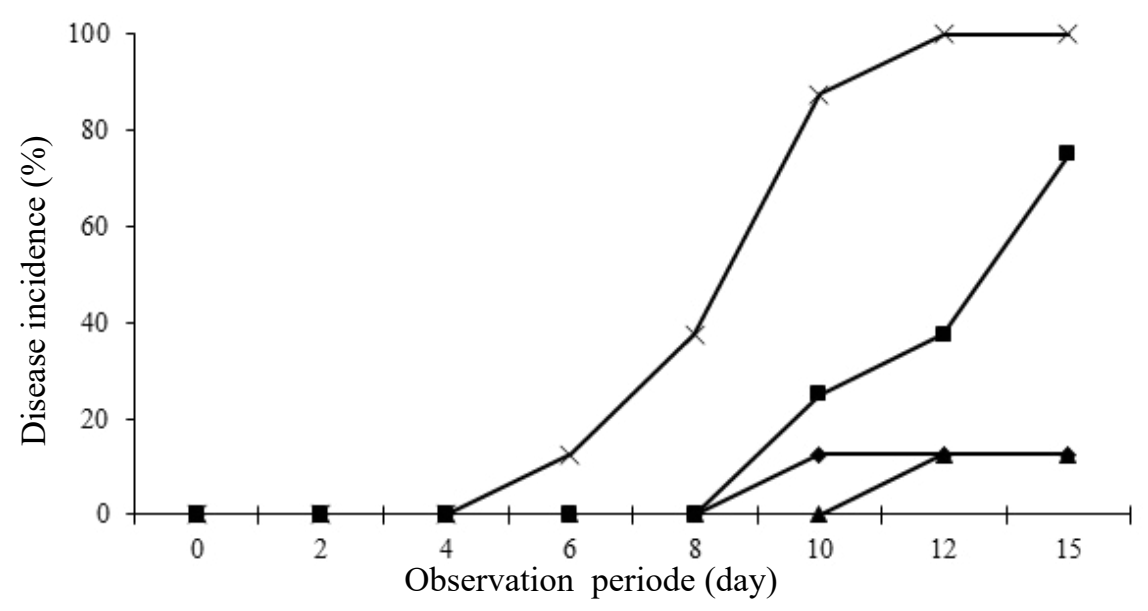

Figure 4 Disease incidence (\%) of anthracnose in post-harvest chili with different treatments of storage. ZECC.n $(\rightarrow)$ ): non-inoculated chili stored in ZECC; ZECC.in $(-\boldsymbol{-})$ : inoculated chili stored in ZECC; Room.n ( $\nleftarrow)$ : non-inoculated chili stored in room temperature; and Room.in $(\underset{*}{*})$ : inoculated chili stored in room temperature.

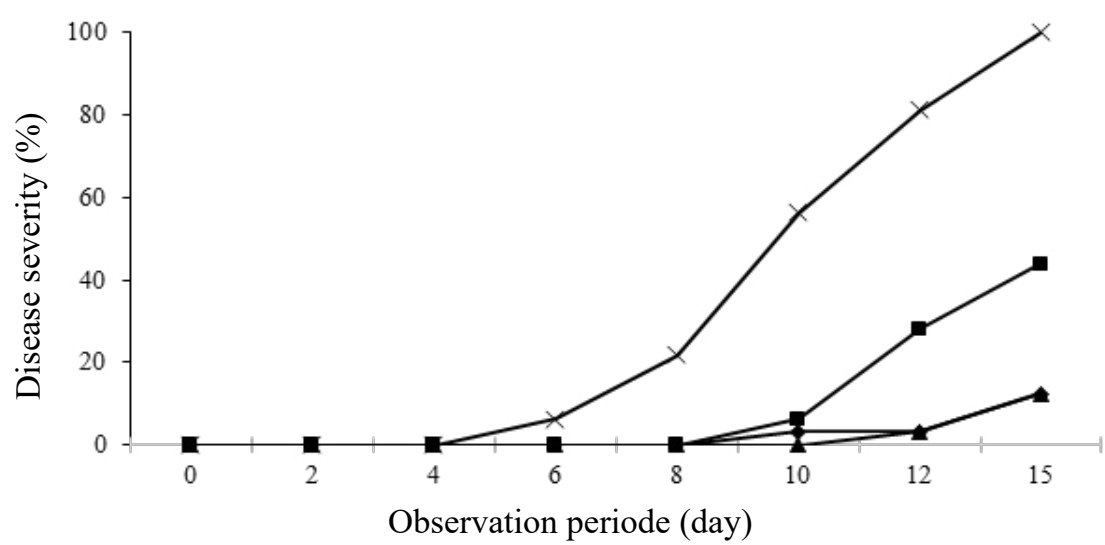

Figure 5 Disease severity (\%) of anthracnose in post-harvest chili with different treatments of storage. ZECC.n $(\rightarrow)$ ): non-inoculated chili stored in ZECC; ZECC.in $(-\boldsymbol{-})$ : inoculated chili stored in ZECC; Room.n ( $\neg$ ): non-inoculated chili stored in room temperature; and Room.in $(\underset{\leftarrow}{*})$ : inoculated chili stored in room temperature. 
Table 4 Vitamin C content, total soluble solid (TSS) and weight loss of postharvest chili after 15 days' storage

\begin{tabular}{lccc}
\hline Treatment & $\begin{array}{c}\text { Vitamin C content } \\
(\mathrm{mg})\end{array}$ & $\begin{array}{c}\text { Total soluble solid } \\
(\mathrm{TSS})\end{array}$ & $\begin{array}{c}\text { Weight loss } \\
(\%)\end{array}$ \\
\hline ZECC.n & $23.03 \mathrm{a}$ & $6.35 \mathrm{a}$ & $7.60 \mathrm{bc}$ \\
ZECC.in & $23.03 \mathrm{a}$ & $6.98 \mathrm{a}$ & $5.53 \mathrm{c}$ \\
Ruang.n & $19.97 \mathrm{a}$ & $6.33 \mathrm{a}$ & $9.70 \mathrm{~b}$ \\
Ruang.in & $24.97 \mathrm{a}$ & $6.25 \mathrm{a}$ & $14.89 \mathrm{a}$ \\
\hline
\end{tabular}

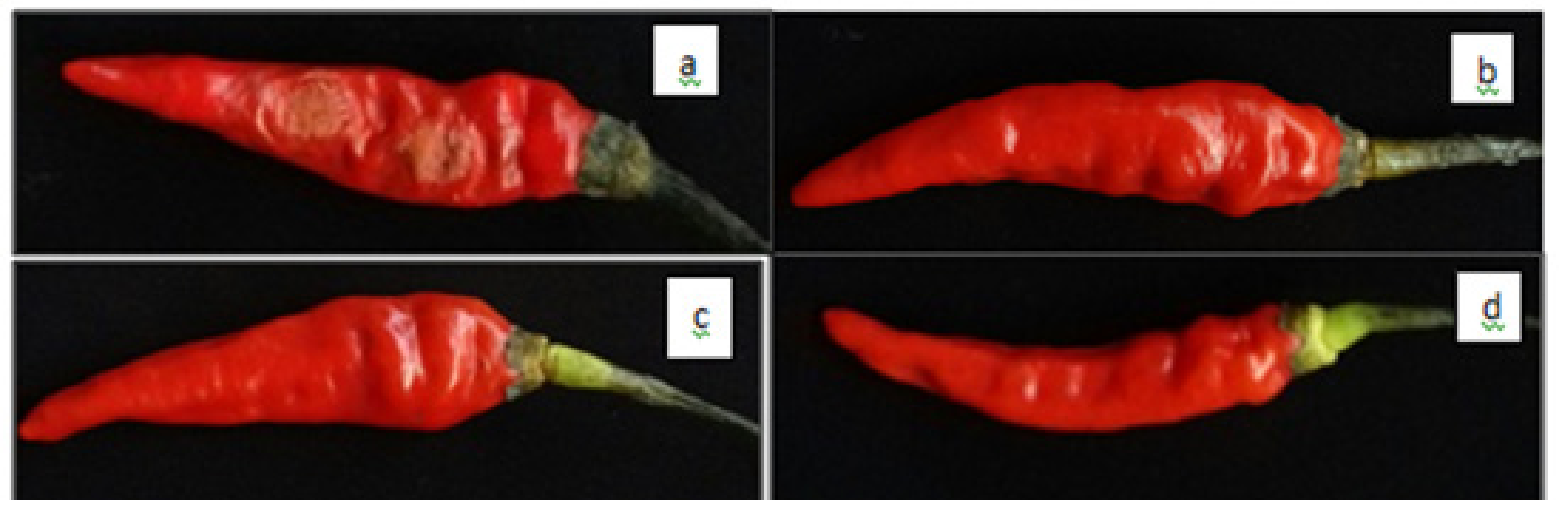

Figure 6 Morphology of postharvest chili in different storage 9 days after treatment. a, Inoculated chili stored in room temperature (Room.in.); b, Non-inoculated chili stored in room temperature (Room.n); c, Inoculated chili stored in ZECC (ZECC.in); and d, Non-inoculated chili stored in ZECC (ZECC.n).
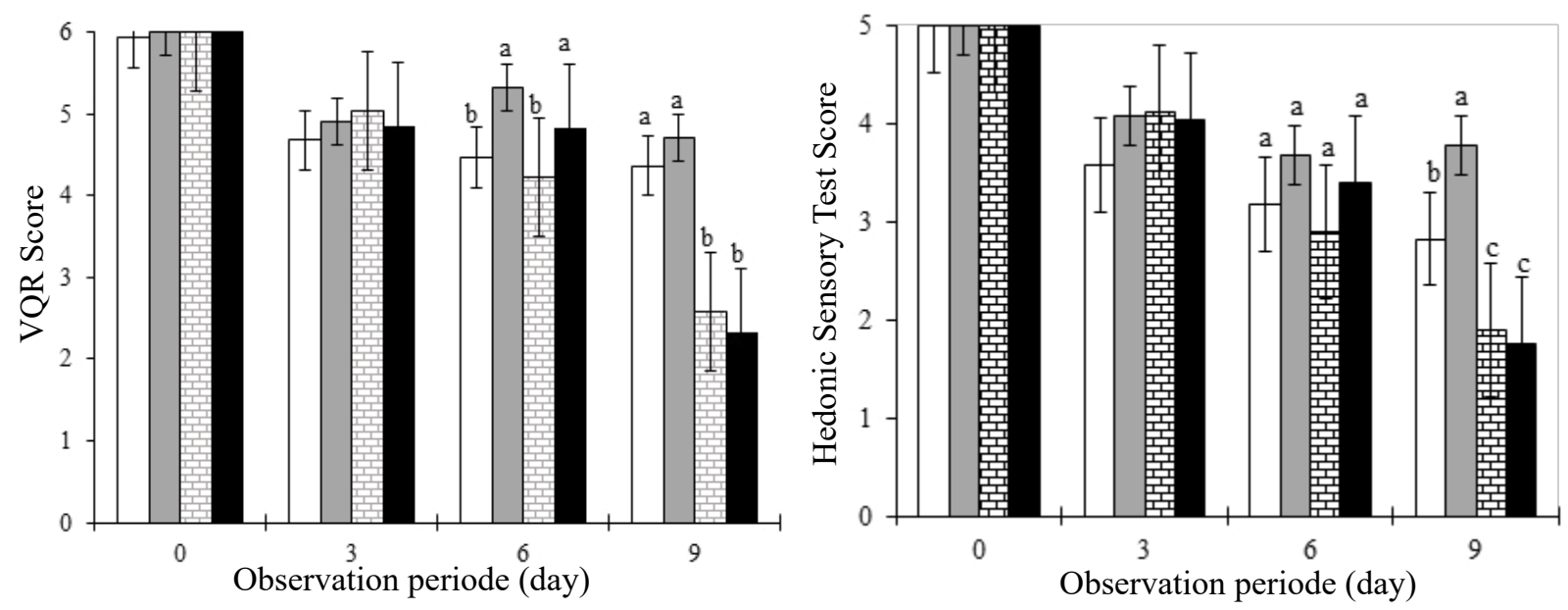

Figure 7 Visual Quality Rating (VQR) test and Hedonic Sensory Test result of postharvest chili kept in different storage. Same letters showed no significantly different by LSD at $95 \%$ level of confident. ZECC.n ( $\square$ ): non-inoculated chili stored in ZECC; ZECC.in ( $\square$ ): inoculated chili stored in ZECC; Room.n ( $\mathbf{\square})$ : non-inoculated chili stored in room temperature; and Room.in (田): inoculated chili stored in room temperature.

severity of inoculated chili stored in ZECC were lower compared to inoculated chili in room temperature. Incubation period based on the symptom appearance was also slower for inoculated chili stored in ZECC compared to same treatment in room temperature. These data showed that low temperature in ZECC may inhibit the pathogen development and delay the infection process, while its high humidity possibly maintains the freshness of chili. Lower temperature and higher relative humidity in ZECC cooling chambers 
contributed to the improved shelf life of fruit and vegetables as this condition will decrease the transpiration rate of fruits and vegetables (Islam and Marimoto 2012; Islam et al. 2012; Dirpan et al. 2017). This condition may indirectly support the sturdiness of chili fruits' tissue to be unsuitable for latent infection of C. gloeosporioides. Symptom appearance on uninoculated chili both in ZECC and room temperature indicated, that infection probably had already happened from the field. It supports fact that proper postharvest handling is critical to maintain the quality of agricultural products until they reach consumer's hand.

TSS and vitamin $\mathrm{C}$ content showed that different storage room up to 15 days did not influence quality of chili by parameters of vitamin $\mathrm{C}$ content and TSS. However, weight loss was significantly reduced on inoculated chili stored in ZECC compared to chili stored in room temperature both for inoculated and uninoculated treatment. Weight loss of chili stored in ZECC both inoculated and uninoculated were not significantly different, indicated that humidity helped chili to maintain their freshness. Weight loss of fruit and vegetable products due to the transpiration process were suppressed by the high rate of relative humidity (RH) in air (Islam and Marimoto 2012). The high relative humidity value was kept high in ZECC during this experiment and resulted in low weight loss due to inhibition of metabolic process such as transpiration. The effect of weight loss to the vitamin $\mathrm{C}$ content is still not clearly explained yet.

Both inoculated and non-inoculated chili stored in ZECC showed similar VQR score and their scores were higher compared to chili stored in room temperature. In this experiment, higher score represents better performance of chili as stated that score 5 represents good, small damage fruits; whereas score 3 represents bad fruits and fruits could not be used for sale due to serious damage. Similarly, data of hedonic sensory test showed that up to 9 days' observation, chili stored in ZECC was more preferable by consumers. Taken together from VQR and hedonic sensory test it showed that ZECC storage possess significant impact to the chili quality and consumer's preferences.

This experiment showed that low temperature and high relative humidity may maintain the freshness of postharvest chili and reduced the anthracnose disease incidence and severity. Although TSS and vitamin C content is not significantly different between ZECC and room temperature treatment, ZECC maintained the chili weight and fresh appearance. Due to our best knowledge, this is the first report of evaluation on ZECC to be used for postharvest disease management of anthracnose chili in Indonesia.

\section{ACKNOWLEDGEMENT}

Authors expressed gratitude to Fac. of Agriculture, Universitas Gadjah Mada for financial support to principal researcher (Ani Widiastuti) in Lecturer Grant Program, 2017 and Dr. Lisa Kitinoja(Founder, The Postharvest Education Foundation) for education support and technology to Ani Widiastuti as PEF alumni 2016. This article is part of undergraduate thesis entitled "Zero-Energy Cool Chamber for Managing Anthracnose Disease and Quality of Postharvest Chili in 2017" conducted by Nuzila Fitri Filaila under supervision of Ani Widiastuti and Suryanti.

\section{REFERENCES}

Dirpan A, Sapsal MT, Muhammad AK, Tahir MM, Rahimuddin. 2017. Evaluation of temperature and relative humidity on two types of zero energy cool chamber (ZECC) in South Sulawesi, Indonesia. IOP Conf Ser: Earth Environ Sci. DOI: https://doi. org/10.1088/1755-1315/101/1/012028.

Islam MP, Morimoto T, Hatou K. 2012. Storage behavior of tomato inside a zero energy cool chamber. Agric Eng Int: CIGR J. 14(4):209-217.

Islam MP, Morimoto T. 2012. Zero energy cool chamber for extending the shelf life 
of tomato and eggplant. JARQ. 46(3):257267. DOI: https://doi.org/10.6090/ jarq.46.257.

Kitinoja L, Kader AA. 2015. Measuring postharvest losses of fresh fruits and vegetables in developing countries. Report number: White Paper No. 15-02 The Postharvest Education Foundation DOI: $\quad$ http://dx.doi.org/10.13140/ RG.2.1.3921.6402.

Mishra A, Jha SK, Ojha P. 2020. Study on Zero energy cool chamber (ZECC) for storage of vegetables. Int J Sci Res Publ. 10(1):427-433. DOI: https://doi. org/10.29322/IJSRP.10.01.2020.p9767.

Montri P, Taylor P, Mongkolporn O. 2009. Pathotypes of Colletotrichum capsici, the causal agent of chili anthracnose, in Thailand. Plant Dis. 93(1):17-20. DOI: https://doi.org/10.1094/PDIS-93-1-0017.

Rayaguru K, Khan Md K, and Sahoo NR. 2010. Water use optimization in Zero
Energy Cool Chambers for short term storage of fruits and vegetables in coastal area. J Food Sci Technol. 47(4):437-441. DOI: https://doi.org/10.1007/s13197-0100072-7.

Régo ER, Régo MM, Matos IWF, Barbosa LA. 2011. Morphological and chemical characterization of fruits of Capsicum spp. accessions. Hortic Bras. 29(3):364371. DOI: https://doi.org/10.1590/S010205362011000300018.

Taufik M. 2010. Farming analysis and postharvest handling of red chili. J Litbang Pertan. 30(2):66-72.

Tsegay D, Tesfaye B, Mohammed A, Yirga H, Bayleyegn A. 2013. Effects of harvesting stage and storage duration on postharvest quality and shelf life of sweet bell pepper (Capsicum annuum L.) varieties under passive refrigeration system. Int $\mathbf{J}$ Biotechnol Mol Biol Res. 4(7):98-104. 